\title{
The promising immune checkpoint LAG-3: from tumor microenvironment to cancer immunotherapy
}

\author{
Long Long ${ }^{1,2}$, Xue Zhang ${ }^{1}$, Fuchun Chen ${ }^{3}$, Qi Pan ${ }^{3}$, Pronnaphat Phiphatwatchara ${ }^{1}$, \\ Yuyang Zeng ${ }^{1}$ and Honglei Chen ${ }^{1}$ \\ ${ }^{1}$ Department of Pathology, School of Basic Medical Science, Wuhan University, Wuhan, P. R. China \\ 2 Department of Radiation and Medical Oncology, Zhongnan Hospital, Wuhan University, Wuhan, P. R. China \\ ${ }^{3}$ Department of Thoracosurgery, Traditional Chinese Medical Hospital of Wenling, Wenling, Zhejiang, China \\ Correspondence to: Honglei Chen, email: hl-chen@whu.edu.cn
}

Keywords: immune checkpoint; lymphocyte activation gene-3; cancer immunotherapy; tumor microenvironment Received: August 13,2018 Accepted: September 16, $2018 \quad$ Published: September 23, 2018

Copyright: Long et al. This is an open-access article distributed under the terms of the Creative Commons Attribution License 3.0 (CC BY 3.0), which permits unrestricted use, distribution, and reproduction in any medium, provided the original author and source are credited.

\section{ABSTRACT}

\begin{abstract}
Cancer immunotherapy and tumor microenvironment have been at the forefront of research over the past decades. Targeting immune checkpoints especially programmed death 1 (PD-1)/programmed death ligand 1 (PD-L1) has made a breakthrough in treating advanced malignancies. However, the low response rate brings a daunting challenge, changing the focus to dig deeply into the tumor microenvironment for alternative therapeutic targets. Strikingly, the inhibitory immune checkpoint lymphocyte activation gene-3 (LAG-3) holds considerable potential. LAG3 suppresses $T$ cells activation and cytokines secretion, thereby ensuring immune homeostasis. It exerts differential inhibitory impacts on various types of lymphocytes and shows a remarkable synergy with PD-1 to inhibit immune responses. Targeting LAG-3 immunotherapy is moving forward in active clinical trials, and combination immunotherapy of anti-LAG-3 and anti-PD-1 has shown exciting efficacy in fighting PD-1 resistance. Herein, we shed light on the significance of LAG-3 in the tumor microenvironment, highlight its role to regulate different lymphocytes, interplay with other immune checkpoints especially PD-1, and emphasize new advances in LAG-3targeted immunotherapy.
\end{abstract}

\section{INTRODUCTION}

Over the past decades, the extraordinary advances in cancer immunotherapy have opened a new era for tumor microenvironment (TME). TME contains tumor cells, cancer-associated fibroblasts (CAFs), endothelial cells, myelomonocytic cells, myeloid-derived suppressor cells (MDSCs), tumor-infiltrating lymphocytes (TILs), extracellular matrix (ECM), and vasculatures [1]. Interactions between various components of the tumor microenvironment are complex and unique, therefore playing a vital role in tumor initiation, malignant progression, metastasis as well as therapeutic efficacy [2, $3]$.

Immune checkpoints are essential molecules to regulate $\mathrm{T}$ cells function in the tumor microenvironment [4]. Immune checkpoint therapy, which blocks inhibitory pathways in $\mathrm{T}$ cells to promote anti-tumor immune responses, has remarkably revolutionized cancer treatment paradigms [5]. The fully unraveled primary immune checkpoints are programmed cell death-1 (PD1)/programmed cell death ligand-1 (PD-L1), and cytotoxic T-lymphocyte antigen-4 (CTLA-4) [5]. Furthermore, PD-1/PD-L1 inhibitors have already been approved by the Food and Drug Administration (FDA) for treating melanoma, non-small cell lung cancer (NSCLC) and other malignancies [6].

Despite the impressive clinical success of immune checkpoint therapy, tumor intrinsic resistance remains a daunting challenge, leading to low response rate in large-scale use of immune checkpoint inhibitors in solid tumors $[3,4]$. To permit more patients to benefit from immunotherapy, the focus has changed to targeting alternative novel immune checkpoints in the tumor microenvironment [7], such as lymphocyte activation 
gene-3 (LAG-3) [8], T cell immunoglobulin and mucin domain 3 (TIM-3) [9], V-domain immunoglobulincontaining suppressor of T-cell activation (VISTA) [10], and human endogenous retrovirus-H long terminal repeatassociating protein 2 (HHLA2) [11](Figure 1).

LAG-3 (CD223) may be a significantly promising immune checkpoint, which is a co-inhibitory receptor to suppress $\mathrm{T}$ cells activation and cytokines secretion, thereby ensuring a state of immune homeostasis [12]. LAG-3 exerts differential inhibitory impacts on various types of lymphocytes [13]. Meanwhile, LAG-3 can effectively prevent the onset of autoimmune disorders [14]. The precise molecular mechanisms of LAG-3 signaling and interaction with other immune checkpoints are mostly unclear. However, LAG-3 shows a striking synergy with PD-1 in multiple settings to inhibit immune responses [15]. LAG-3-targeted immunotherapy started in 2006 with a LAG-3 Ig fusion protein (IMP321), and there are currently several LAG-3-modulating treatments in various phases of clinical development $[12,16-18]$. In particular, combination therapy of antiLAG-3 (BMS-986016) plus anti-PD-1 (nivolumab) has shown impressive clinical efficacy in melanoma patients who are resistant to anti-PD-1/PD-L1 therapy $[19,20]$. In this review, we provide a detailed description of the significance of the promising immune checkpoint LAG3 in the tumor microenvironment, discuss its role on different types of lymphocytes and autoimmune disorders, highlight its interplay with other immune checkpoints, as well as outline the new advances targeting LAG-3 in cancer immunotherapy.

\section{LAG-3 SIGNALING AND ITS EXPRESSION IN HUMAN TUMORS}

LAG-3 is a surface molecule located closely to CD4 but sharing less than $20 \%$ homology at the amino acid level [21]. Similar to CD4, LAG-3 binds to major histocompatibility complex-II (MHC-II) on antigenpresenting cells (APCs), but with a much stronger affinity [21]. LAG-3 is expressed on the cell membranes of TILs [22], activated $\mathrm{CD}^{+}[23]$ and $\mathrm{CD}^{+} \mathrm{T}$ cells [24] as well as regulatory $\mathrm{T}$ cells (Tregs) [25]. It is also expressed on natural killer (NK) cells [26], B cells [27], and dendritic cells (DCs) [28]. LAG-3 belongs to the immunoglobulin

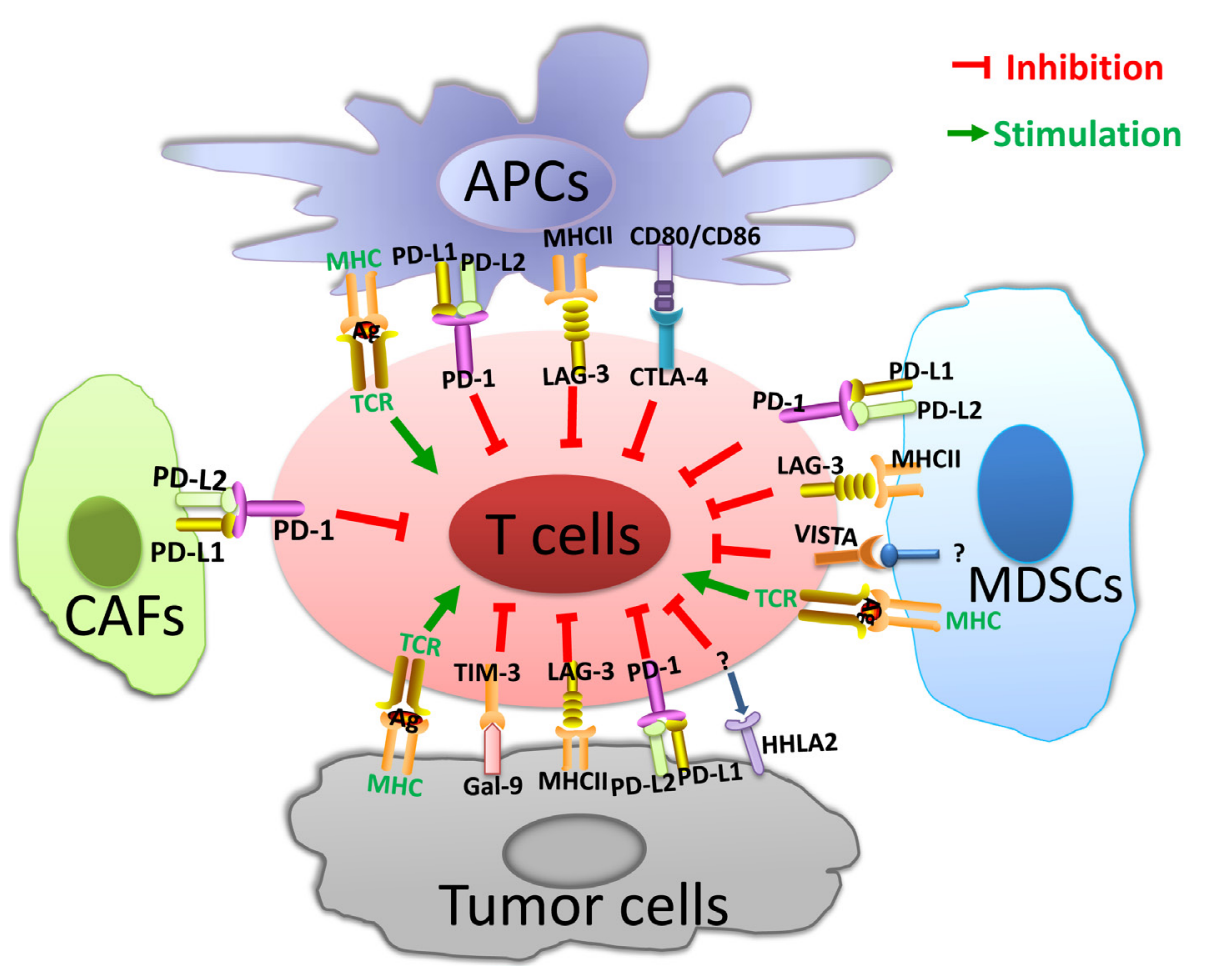

Figure 1: Tumor microenvironment and immune checkpoints. In the TME, APCs present tumor antigens to naïve T cells and induce T-cell activation. The MHC and TCR signaling pathway provide the first signal for T-cell activation, while co-inhibitory immune checkpoints collaborate to suppress T-cell activation in the TME. Immune checkpoints are presented on T cells. Ligands are expressed on APCs, tumor cells and other stromal cells, such as CAFs and MDSCs. Abbreviations: TME = tumor microenvironment; APCs = antigen presenting cells; MDSCs = myeloid-derived suppressor cells; CAFs = cancer-associated fibroblasts; MHC = major histocompatibility complex; TCR = T-cell receptor; PD-1 = programmed death 1; PD-L1 = programmed cell death ligand-1; PD-L2 = programmed cell death ligand-2; LAG-3 = lymphocyte activation gene-3; CTLA-4 = cytotoxic T-lymphocyte antigen-4; VISTA = V-domain immunoglobulincontaining suppressor of T-cell activation; HHLA2 = human endogenous retrovirus-H long terminal repeat-associating protein 2; TIM-3 = T cell immunoglobulin and mucin domain 3; Gal-9 = Galectin-9; MDSCs = myeloid-derived suppressor cells. 
Table 1: Expression of LAG-3 in different human tumors and its clinicopathological associations

\begin{tabular}{|l|l|l|l|l|}
\hline \multicolumn{1}{|c|}{ Type of tumor } & LAG-3 Expression & Level & \multicolumn{1}{c|}{ Clinicopathological associations } & Ref. \\
\hline Melanoma & Various TILs & High & Resistance and survival of melanoma cells & {$[32]$} \\
\hline Hodgkin's lymphoma & TILs, PBLs & High & Suppression of EBV-specific T cell function & {$[34]$} \\
\hline $\begin{array}{l}\text { Chronic lymphocytic } \\
\text { leukemia }\end{array}$ & CLL cells, TILs, PBLs & High & $\begin{array}{l}\text { The unmutated immunoglobulin variable } \\
\text { heavy chain leukemic subtype and short time to } \\
\text { treatment }\end{array}$ & {$[35]$} \\
\hline Colorectal cancer & TILs & High & $\begin{array}{l}\text { Differentiation, lymph metastasis, invasion, TNM, and } \\
\text { Duke stage }\end{array}$ & {$[36]$} \\
\hline Ovarian cancer & TILs, PBLs & High & Impaired function of NY-ESO-1-specific CD8 ${ }^{+}$T cells & {$[37]$} \\
\hline $\begin{array}{l}\text { Hepatocellular } \\
\text { carcinoma }\end{array}$ & TILs & High & HBV-specific CD8 ${ }^{+}$T cells dysfunction & {$[38]$} \\
\hline Renal cell carcinoma & TILs & High & Poor prognostic impact & {$[39]$} \\
\hline Gastric cancer & CD4+ and CD8 ${ }^{+}$T cells & High & Positive correlation with PD-1 expression & {$[40]$} \\
\hline Follicular lymphoma & Intratumoral T cells & High & Poor outcome & {$[41]$} \\
\hline Prostate cancer & TILs, PBLs & High & Histological signs of malignancy & {$[42]$} \\
\hline $\begin{array}{l}\text { Head and neck squamous } \\
\text { cell carcinoma }\end{array}$ & TILs & High & $\begin{array}{l}\text { High pathological grades, lager tumor size, positive } \\
\text { lymph node status and poor prognosis }\end{array}$ & {$[43]$} \\
\hline $\begin{array}{l}\text { Non-small cell lung } \\
\text { cancer }\end{array}$ & TILs & High & $\begin{array}{l}\text { TIL abundance, PD-1/PD-L1 expression, and reduced } \\
\text { survival }\end{array}$ & {$[44]$} \\
\hline $\begin{array}{l}\text { Malignant } \\
\text { pleural mesothelioma }\end{array}$ & TILs & High & PD-1/PD-L1 expression, and immune cell activation & {$[45]$} \\
\hline Breast cancer & TILs & High & $\begin{array}{l}\text { ER- subtypes, PD-1/PD-L1 tumors and improved } \\
\text { survival }\end{array}$ & {$[46]$} \\
\hline $\begin{array}{l}\text { Anal squamous } \\
\text { cellcarcinoma }\end{array}$ & TILs & High & PD-1/PD-L1 expression & {$[47]$} \\
\hline Pancreatic cancer & TILs & PD-1 and CTLA-4 expression & {$[48]$} \\
\hline
\end{tabular}

$\mathrm{TIL}=$ Tumor-infiltrating lymphocytes; PBLs=Peripheral blood T cells; EBV=Epstein-Barr virus; HBV = Hepatitis B Virus; $\mathrm{CLL}=$ Chronic lymphocytic leukemia; LAG-3=Lymphocyte activation gene-3; TNM=The TNM Classification of Malignant Tumors; PD-1=Programmed death 1; ER= Estrogen-receptor; CTLA-4 = Cytotoxic T lymphocyte antigen 4.

superfamily (IgSF) and associates with the CD3/T cell receptor (TCR) complex [29]. LAG-3 interacts with MHCII to prohibit the binding of the same MHC molecule to TCR and CD4, thus directly hindering TCR signaling in immune response [13]. Crosslinking of LAG-3 and CD3 can impair T cell proliferation and cytokine secretion by inhibiting calcium ion fluxes [29]. The exact signaling transduction mechanism of LAG-3 is still not well elucidated. Nonetheless, the cytoplasmic tail of LAG-3 is quite distinct from other immune checkpoints, suggesting its unique molecular characteristics. It has three conserved domains: the first region may be a possible serine phosphorylation site; the second is KIEELE motif (Figure 2 ), which is crucial in regulating $\mathrm{CD} 4^{+} \mathrm{T}$ cell function; and the third is glutamic acid-proline (EP) repeat, binding to LAG-3-associated protein (LAP), thereby aid to localizing LAG-3 [21]. LAG-3 intrinsic signaling transmits via the cytoplasmatic KIEELE motif [30]. It prevents $\mathrm{T}$ cells to enter the S-phase of the cell cycle and consequently results in suppression of T-cell expansion [30, 31]. However, the intracellular binding partners of KIEELE motif are unidentified.

Besides, the LAG-3/MHC-II interaction may also act as bidirectional inhibitory signaling shared by immune cells and tumor cells [32]. Over-expression of LAG-3 in T cells can protect MHC-II-expressing melanoma cells from drug-induced or FAS-mediated apoptosis through MAPK/ ERK and PI3K/AKT survival pathways [32]. Meanwhile, LAG-3-expressing Tregs may utilize an immune tyrosinebased activation motif (ITAM)-modulated suppressive signaling pathway, containing Fc $\gamma \mathrm{R} \gamma$ and ERK-modulated recruitment of SHP-1, to indirectly inhibit the function of DCs [33].

Aberrant LAG-3 expression has been found in a broad spectrum of human tumors such as melanoma, NSCLC, colorectal cancer, breast cancer, hepatocellular carcinoma, follicular lymphoma, head and neck squamous cell carcinoma, etc, which is significantly associated with aggressive tumor progression and clinicopathological characteristics (summarized in Table 1) [32, 34-48].

\section{ROLE OF LAG-3 ON TILS}

TILs are essential components in the complex landscape of the tumor immune microenvironment, which consists of $\mathrm{CD}^{+} \mathrm{T}$ cells, $\mathrm{CD} 8^{+} \mathrm{T}$ cells, Tregs, NK cells, $B$ cells, macrophages and DCs [49]. Over-expression of LAG-3 is detected on various TILs, exhibiting significant 
immune regulatory impacts (Table 2).

\section{LAG-3 on CD4 ${ }^{+}$T cells}

Tumor-infiltrating $\mathrm{CD}^{+} \mathrm{T}$ cells exhibit traits of chronic exhaustion during tumor progression, accompanied by up-regulation of inhibitory receptor LAG-3 [50]. As an MHC-II ligand, LAG-3/MHC-II interaction negatively modulates $\mathrm{CD}^{+} \mathrm{T}$ cells expansion and suppresses cytokine response [50, 51]. Increasing evidence has clarified that the specific KIEELE motif in the cytoplasmic tail is indispensable for abrogating effector $\mathrm{CD}^{+} \mathrm{T}$ cells [52]. It can mediate intracellular downstream signal transduction, prevent the entry of $\mathrm{T}$ cells into the growth phase of the cell cycle, and depletion of this region is ineffective to negatively regulate $\mathrm{T}$ cell function in vitro or in vivo [52]. Moreover, LAG-3 expression on $\mathrm{CD}^{+} \mathrm{T}$ cells links to gamma-chain cytokines including interleukin-2,7,12 (IL-2,7,12) and (interferon- $\gamma$ ) IFN- $\gamma$ [23]. Another study demonstrates that LAG-3 blockade can potentially affect $\mathrm{CD} 4^{+} \mathrm{T}$-cell populations, lead to a relative skewing from a Treg phenotype and modulate the function of $\mathrm{CD}^{+} \mathrm{T}$ cells to be suppressed $[23,53]$. Of note, LAG-3 signal can elevate sensitivity to Treg cells, which can mediate chronic exhaustion and inhibition of $\mathrm{CD}^{+} \mathrm{T}$ cells during cancer recurrence [50].

\section{LAG-3 on CD8 ${ }^{+}$T cells}

Un-activated $\mathrm{CD}^{+} \mathrm{T}$ cells express slight levels of LAG-3, while LAG-3 expression remarkably elevates in response to antigenic stimulus [54]. In self-tolerance models, LAG-3 blockade enhances the effector function of $\mathrm{CD}^{+} \mathrm{T}$ cells and elicits higher production of IFN- $\gamma$, suggesting the specific role of LAG-3 in limiting selftolerance. Moreover, the impact is not dependent on $\mathrm{CD}^{+}$ $\mathrm{T}$ cells [55]. Accumulating evidence has delineated that LAG-3 is over-expressed on tumor-infiltrating $\mathrm{CD}^{+}$ $\mathrm{T}$ cells in various tumor types, such as ovarian cancer, hepatocellular carcinoma, renal cell carcinomas and other solid tumors [32, 37, 38, 40, 41, 44, 56, 57]. Despite the studies which provide insight into the intrinsic mechanism of $\mathrm{LAG}-3 / \mathrm{CD} 8$ interaction remain scarce, it is newly reported that there may exist two additional LAG-3

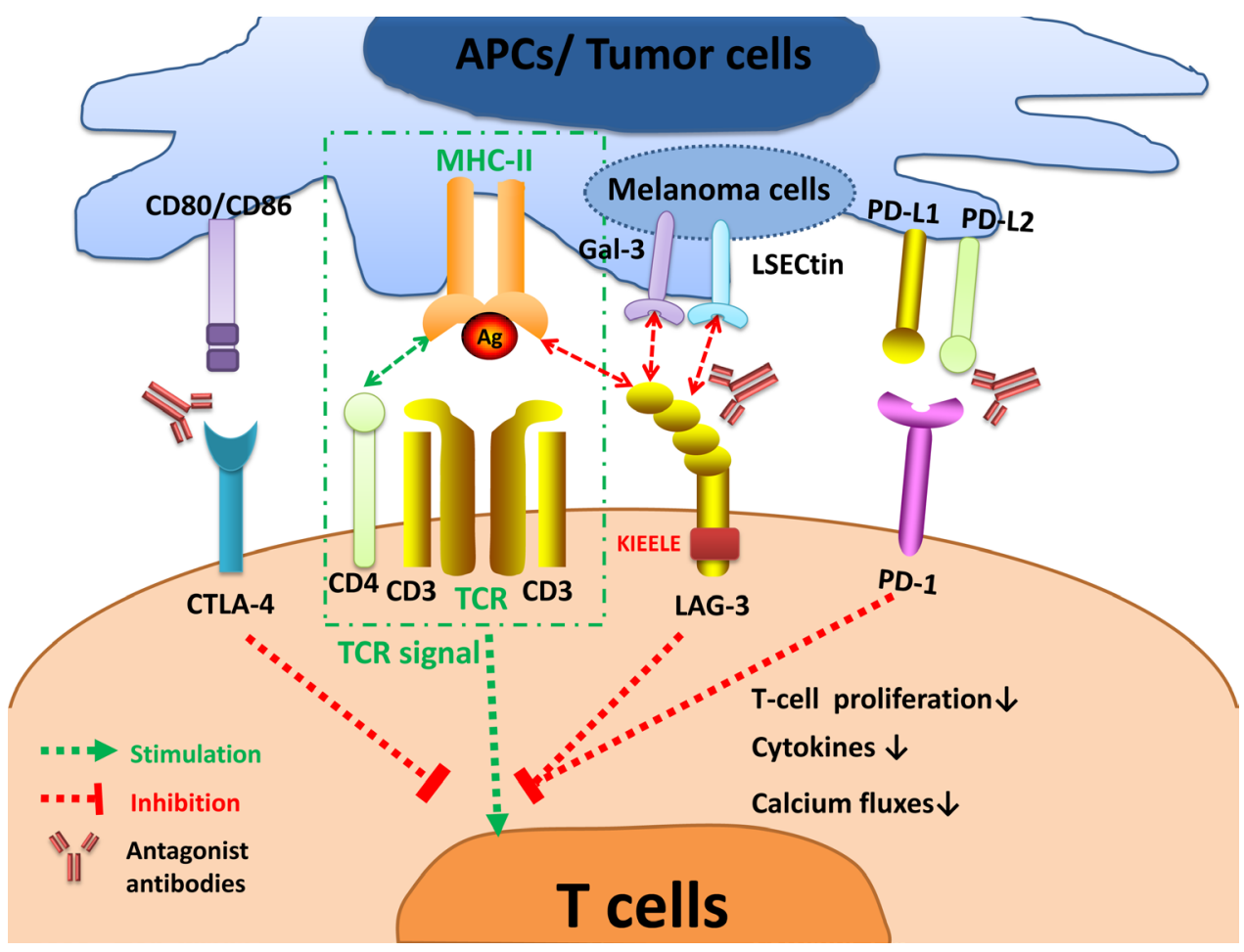

Figure 2: LAG-3 signaling and the interplay with other immune checkpoints. The interaction of LAG-3 with MHC-II prohibits the binding of the same MHC molecule to a TCR and CD4, thus suppressing TCR signal. LAG-3 transmits an inhibitory signal via the KIEELE motif in the cytoplasmic tail. Crosslinking of LAG-3 and CD3/TCR complex can impair T cell proliferation, cytokines secretion, and calcium ion fluxes. LAG-3 also interacts with two novel ligands postulated, Gal-3 and LSECtin, expressed on melanoma cells to modulate $\mathrm{CD}^{+}$T-cell function within the TME. Strikingly, LAG-3 inhibits T-cell activation collectively with other immune checkpoints, especially PD-1. Antagonist antibodies targeting inhibitory immune checkpoints can restore T-cell function and have shown benefits in active clinical trials. Abbreviations: APCs = antigen presenting cells; $\mathrm{MHC}=$ major histocompatibility complex; TCR = T-cell receptor; PD-1 = programmed death 1; PD-L1 = programmed cell death ligand-1; LAG-3 = lymphocyte activation gene-3; CTLA-4 = cytotoxic T-lymphocyte antigen-4; Gal-3 = Galectin-3; LSECtin = Liver sinusoidal endothelial cell lectin. 
Table 2: The correlation between LAG-3 and TILs

\begin{tabular}{|c|c|c|c|c|}
\hline $\begin{array}{l}\text { Types of } \\
\text { TILs }\end{array}$ & $\begin{array}{c}\text { LAG-3 } \\
\text { expression }\end{array}$ & Correlations & Influence factors & Ref. \\
\hline $\mathrm{CD}^{+}{ }^{+} \mathrm{T}$ cells & Elevated & $\begin{array}{l}\text { LAG-3 negatively } \\
\text { regulates } \mathrm{CD}^{+} \mathrm{T} \text { cell } \\
\text { activation. }\end{array}$ & $\begin{array}{l}\text { LAG-3/MHC-II interaction, KIEELE } \\
\text { motif, gamma-chain cytokines (IL-2, IL-7, } \\
\text { IL-12 and IFN- } \gamma \text { ), and Tregs }\end{array}$ & {$[23,50-53]$} \\
\hline $\mathrm{CD}^{+} \mathrm{T}$ cells & Elevated & $\begin{array}{l}\text { LAG-3 dampens the } \\
\text { effector function of } \mathrm{CD} 8^{+} \\
\text {T cells. }\end{array}$ & $\begin{array}{l}\text { Co-inhibitory molecules especially PD-1, } \\
\text { LSECtin and galectin-3 }\end{array}$ & $\begin{array}{l}{[15,32,37} \\
38,40,41 \\
44,54-60]\end{array}$ \\
\hline Tregs & Elevated & $\begin{array}{l}\text { LAG-3 promotes Tregs } \\
\text { suppressor activity. }\end{array}$ & $\begin{array}{l}\text { Co-inhibitory molecules, cytokines TGF- } \beta \\
\text { and IL-10 }\end{array}$ & $\begin{array}{c}{[23,25,61-} \\
64]\end{array}$ \\
\hline NK cells & Elevated & $\begin{array}{l}\text { LAG-3 inhibits NKT cells } \\
\text { proliferation. }\end{array}$ & IL-12 & {$[26,65-69]$} \\
\hline $\mathrm{pDCs}$ & Elevated & $\begin{array}{l}\text { LAG-3 suppresses pDCs } \\
\text { activation. }\end{array}$ & IL- 6 enrichment and IFN- $\alpha$ deficiency & {$[33,70,71]$} \\
\hline
\end{tabular}

MHC-II= Major histocompatibility complex-II; PD-1=Programmed death 1; LSECtin=Liver sinusoidal endothelial cell lectin; Tregs=T regulatory cells; $\mathrm{NKT}=$ Natural killer cells that can also express T cell receptors; $\mathrm{pDCs}=$ plasmacytoid dendritic cells; $\mathrm{IL}=$ Interleukin; IFN= Interferon; TGF= Transforming growth factor.

ligands in the tumor microenvironment to help regulate $\mathrm{CD}^{+} \mathrm{T}$ cells-galectin-3 and Liver sinusoidal endothelial cell lectin (LSECtin), which could effectively abolish anti-tumor immunity of $\mathrm{CD}^{+} \mathrm{T}$ cells via LAG-3 [58, 59]. Furthermore, it is conspicuous that $\mathrm{CD} 8^{+} \mathrm{T}$ cells can express LAG-3 concurrent with multiple co-inhibitory immune checkpoints especially PD-1 [60], which are manifested to mark the dysfunction of $\mathrm{CD}^{+}$TILs [15].

\section{LAG-3 on Tregs}

In the TME, Tregs are considered as the culprit to deteriorate anti-tumor immune responses, which can impede cytokines production and enhance suppressor activity [25, 61]. LAG-3 is essential for maximal Treg suppressive function and confers to a regulatory phenotype [25]. More recent studies have described that LAG-3 promotes Treg differentiation, while LAG-3 blockade mitigates Treg induction [23]. Tumor-infiltrating Tregs are featured in the enhancement of accumulation of forkhead box P3 (Foxp3) together with inhibitory molecules such as PD-1, CTLA-4, LAG-3, and TIM-3 during tumor progression [62]. The finding is strongly supported by the research in NSCLC patients, in which LAG-3 expression on tumor-infiltrating Tregs is elevated, compared to peripheral blood and normal adjacent tissues. Besides, tumor-infiltrating Foxp $3^{+} \mathrm{LAG}-3^{+}$Tregs secrete a higher level of immunosuppressive cytokines IL-10 and transforming growth factor- $\beta$ (TGF- $\beta$ ) to collectively magnify Tregs activity $[63,64]$.

\section{LAG-3 on NK cells}

NK cells are predominant defenders in innate immunity against tumors. The studies exploring the underlying mechanism of LAG-3, firstly found on activated NK cells, are still insufficient. Knockout of LAG-3 gene in mice model resulted in decreased natural killer activity [65]. Interestingly, human NK cells are different from mice. In another research, LAG-3 antibody have no specific influence on human natural killing, of which the mechanism needs further investigation [26]. Compared with no impact on NK cytotoxicity, LAG-3 plays a more critical role in NKT cells that can express both NK receptors and T cell receptors. LAG-3 signaling pathway down-regulates the proliferation of NKT cells by arresting $\mathrm{S}$ phase in the cell cycle [66]. In addition, LAG-3 has also been reported to uniquely exhaust invariant NKT (iNKT) cells and reduce IFN- $\gamma$ production in HIV-infected patients [67]. In the TME, a rise in the expression of LAG3 links to NK cell memory and exhaustion [68]. Besides, recent studies discovered that LAG-3 expression on NK cells is up-regulated in response to IL-12 [68, 69].

\section{LAG-3 on pDCs}

DCs are critical regulators in anti-tumor response with a robust capability to present tumor-specific antigens. According to recent studies, LAG-3 constitutively expresses on plasmacytoid dendritic cells (pDCs) at a higher level than any other DC subset [70]. LAG-3 negatively regulates $\mathrm{pDC}$ activation, is implicated in both intrinsic pDC physiology and cell extrinsic interplay with $\mathrm{T}$ cells, and can be regarded as a significant functional 
Table 3: LAG-3-targeted immunotherapy in clinical trials (Clinical Trials.gov)

\begin{tabular}{|c|c|c|c|c|}
\hline Trial number/ Ref. & Study population & Interventions & Phase & Status/ Outcomes \\
\hline \multicolumn{5}{|c|}{ IMP321 (a soluble LAG-3 Ig) } \\
\hline $\begin{array}{l}\text { NCT00351949 } \\
{[16]}\end{array}$ & $\begin{array}{l}\text { Stage IV renal cell } \\
\text { carcinoma }\end{array}$ & IMP321 & 1 & $\begin{array}{l}\text { Completed, October } 2008 \\
\text { *Induction of effector } \mathrm{CD} 8^{+} \mathrm{T} \text { cells in all } \\
\text { patients } \\
\text { *Reduced tumor growth and better progression- } \\
\text { free survival with high doses }\end{array}$ \\
\hline $\begin{array}{l}\text { NCT00349934 } \\
{[17]}\end{array}$ & $\begin{array}{l}\text { Metastatic breast carcinoma } \\
\text { patients receiving first-line } \\
\text { paclitaxel }\end{array}$ & IMP321 & 1 & $\begin{array}{l}\text { Completed, January } 2010 \\
* \text { Sustained increase/activation of APCs, NK } \\
\text { and CD } 8^{+} \text {effector/memory cells } \\
* 50 \% \text { ORR with IMP321 and paclitaxel } \\
\text { compared with } 25 \% \text { ORR with paclitaxel alone }\end{array}$ \\
\hline $\begin{array}{l}\text { NCT00324623 } \\
{[18]}\end{array}$ & Melanoma (skin) & $\begin{array}{l}\text { Lymphodepletion, vaccine, } \\
\text { IMP321 adjuvant }\end{array}$ & 1 & $\begin{array}{l}\text { Completed, November } 2011 \\
\text { *Induction of more robust and durable cellular } \\
\text { antitumor immune responses }\end{array}$ \\
\hline NCT03252938 & $\begin{array}{l}\text { Solid tumors } \\
\text { Peritoneal carcinomatosis }\end{array}$ & IMP321 & 1 & $\begin{array}{l}\text { Recruiting } \\
\text { Estimated completion, February } 2019\end{array}$ \\
\hline NCT02614833 & $\begin{array}{l}\text { Hormone receptor-positive } \\
\text { metastatic breast cancer }\end{array}$ & $\begin{array}{l}\text { Paclitaxel } \\
\text { Placebo }\end{array}$ & 2 & $\begin{array}{l}\text { Recruiting } \\
\text { Estimated completion, December } 2020\end{array}$ \\
\hline NCT02676869 & $\begin{array}{l}\text { Stage IV melanoma } \\
\text { Stage III melanoma }\end{array}$ & $\begin{array}{l}\text { IMP321 + Pembrolizumab } \\
\text { (Anti-PD-1) }\end{array}$ & 1 & $\begin{array}{l}\text { Recruiting } \\
\text { Estimated completion, December } 2018\end{array}$ \\
\hline \multicolumn{5}{|c|}{ BMS-986016 ( Relatlimab, anti-LAG-3 mAb) } \\
\hline $\begin{array}{l}\text { NCT01968109 } \\
(\text { CA224-020) } \\
{[19,20,92]}\end{array}$ & Advanced solid tumors & $\begin{array}{l}\text { Relatlimab (BMS-986016) } \\
\pm \quad \text { Nivolumab (BMS- } \\
\text { 936558, Anti-PD-1) }\end{array}$ & $1 / 2 \mathrm{a}$ & $\begin{array}{l}\text { Recruiting } \\
\text { Estimated completion, October } 11,2019 \\
\text { *The response rates triple in LAG-3 positive } \\
\text { melanoma patients (LAG-3 expression } \geq 1 \% \text { ). } \\
* \text { A safety profile similar to nivolumab } \\
\text { monotherapy. }\end{array}$ \\
\hline $\begin{array}{l}\text { NCT02966548 } \\
\text { (CA224-034) } \\
\end{array}$ & Advanced solid tumors & $\begin{array}{l}\text { BMS-986016 } \pm \text { Nivolumab } \\
\text { (BMS-936558, Anti-PD-1) }\end{array}$ & 1 & $\begin{array}{l}\text { Recruiting } \\
\text { Estimated completion, July } 1,2020\end{array}$ \\
\hline $\begin{array}{l}\text { NCT03470922 } \\
\text { (CA224-047) }\end{array}$ & $\begin{array}{|lr|}\text { Previously rreated } \\
\text { metastatic or } \text { unresectable } \\
\text { melanoma }\end{array}$ & $\begin{array}{l}\text { Nivolumab (Anti-PD-1) } \pm \\
\text { Relatlimab }\end{array}$ & $2 / 3$ & $\begin{array}{l}\text { Not yet recruiting } \\
\text { Estimated completion, March 16, } 2022\end{array}$ \\
\hline $\begin{array}{l}\text { NCT03459222 } \\
\text { (CA224-048) }\end{array}$ & $\begin{array}{l}\text { Advanced malignant } \\
\text { tumors }\end{array}$ & $\begin{array}{l}\text { Relatlimab } \pm \text { Nivolumab } \\
\text { (Anti-PD-1)+ BMS-986205 } \\
\text { (anti-IDO1)/Ipilimumab } \\
\text { (Anti-CTLA-4) } \\
\end{array}$ & $1 / 2$ & $\begin{array}{l}\text { Not yet recruiting } \\
\text { Estimated completion, May 16, } 2022\end{array}$ \\
\hline NCT02488759 & \begin{tabular}{|l|} 
Virus-positive and virus- \\
negative solid tumors
\end{tabular} & $\begin{array}{l}\text { BMS-986016 + Nivolumab } \\
\text { (Anti-PD-1) }\end{array}$ & $1 / 2$ & $\begin{array}{l}\text { Recruiting } \\
\text { Estimated completion, December 31, } 2019\end{array}$ \\
\hline NCT02060188 & $\begin{array}{l}\text { Recurrent and metastatic } \\
\text { microsatellite high (MSI-H) } \\
\text { and non-MSI-H colon } \\
\text { cancer }\end{array}$ & $\begin{array}{l}\text { BMS-986016 + Nivolumab } \\
\text { (Anti-PD-1) }\end{array}$ & 2 & $\begin{array}{l}\text { Recruiting } \\
\text { Estimated completion, December 31, } 2019\end{array}$ \\
\hline NCT02061761 & Hematologic neoplasms & \begin{tabular}{|l|} 
BMS-986016 \pm Nivolumab \\
(BMS-936558, Anti-PD-1) \\
\end{tabular} & $1 / 2 \mathrm{a}$ & \begin{tabular}{|l|} 
Recruiting \\
Estimated completion, January 15, 2020 \\
\end{tabular} \\
\hline NCT02658981 & $\begin{array}{l}\text { Glioblastoma } \\
\text { Gliosarcoma } \\
\text { Recurrent brain neoplasm }\end{array}$ & $\begin{array}{l}\text { A1: BMS 986016 } \\
\text { A2: Urelumab (Anti- } \\
\text { CD137) } \\
\text { B1: BMS-986016 + } \\
\text { Nivolumab (Anti-PD-1) } \\
\text { B2: Urelumab (Anti- } \\
\text { CD137) + Nivolumab } \\
\text { (Anti-PD-1) }\end{array}$ & 1 & $\begin{array}{l}\text { Recruiting } \\
\text { Estimated completion, December } 2019\end{array}$ \\
\hline NCT02935634 & Advanced gastric cancer & $\begin{array}{l}\text { BMS-986016 + Nivolumab } \\
\text { (Anti-PD-1) }\end{array}$ & 2 & $\begin{array}{l}\text { Recruiting } \\
\text { Estimated completion, November 18, } 2021\end{array}$ \\
\hline NCT02750514 & $\begin{array}{l}\text { Advanced non-small cell } \\
\text { lung cancer }\end{array}$ & $\begin{array}{l}\text { Nivolumab (Anti-PD-1) } \pm \\
\text { BMS-986016 }\end{array}$ & 2 & $\begin{array}{l}\text { Recruiting } \\
\text { Estimated completion, April 29, } 2021 \\
\end{array}$ \\
\hline NCT02996110 & $\begin{array}{l}\text { Advanced renal cell } \\
\text { carcinoma }\end{array}$ & $\begin{array}{l}\text { Nivolumab (Anti-PD-1) }+ \\
\text { Relatlimab / BMS-986205 } \\
\text { (anti-IDO1)/Ipilimumab } \\
\text { (Anti-CTLA-4) }\end{array}$ & 2 & $\begin{array}{l}\text { Recruiting } \\
\text { Estimated completion, January 18, } 2022\end{array}$ \\
\hline NCT03335540 & Advanced cancer & $\begin{array}{l}\text { Nivolumab (Anti-PD-1) } \\
+\quad \text { Relatlimab/ Radiation } \\
\text { Therapy }\end{array}$ & 1 & $\begin{array}{l}\text { Recruiting } \\
\text { Estimated completion, January 31, } 2022\end{array}$ \\
\hline
\end{tabular}




\begin{tabular}{|c|c|c|c|c|}
\hline NCT03365791 & $\begin{array}{l}\text { Advanced solid and } \\
\text { hematologic malignancies. }\end{array}$ & $\begin{array}{l}\text { LAG525 + PDR001 (anti- } \\
\text { PD-1) }\end{array}$ & 2 & $\begin{array}{l}\text { Recruiting } \\
\text { Estimated completion, February 1, } 2021\end{array}$ \\
\hline NCT02460224 & Advanced solid tumors & $\begin{array}{l}\text { LAG525 + PDR001 (anti- } \\
\text { PD-1) }\end{array}$ & $1 / 2$ & $\begin{array}{l}\text { Recruiting } \\
\text { Estimated completion, April 23, } 2019\end{array}$ \\
\hline \multicolumn{5}{|c|}{ REGN3767 (anti-LAG-3 mAb) } \\
\hline NCT03005782 & Malignancies & \begin{tabular}{|l|} 
REGN3767 \pm REGN2810 \\
(Anti-PD-1)
\end{tabular} & 1 & \begin{tabular}{|l} 
Recruiting \\
Estimated completion: October 6, 2020
\end{tabular} \\
\hline \multicolumn{5}{|c|}{ TSR-033 (anti-LAG-3 mAb) } \\
\hline NCT03250832 & Advanced solid tumors & TSR-033 \pm Anti-PD-1 & 1 & $\begin{array}{l}\text { Recruiting } \\
\text { Estimated completion, May } 2021\end{array}$ \\
\hline \multicolumn{5}{|c|}{ MGD013 (a PD-1/LAG-3 bispecific DART ${ }^{\circledR}$ protein) } \\
\hline NCT03219268 & $\begin{array}{l}\text { Advanced solid tumors } \\
\text { Hematologic neoplasms }\end{array}$ & MGD013 & 1 & $\begin{array}{l}\text { Recruiting } \\
\text { Estimated completion, August } 2022\end{array}$ \\
\hline \multicolumn{5}{|c|}{ FS118 (a LAG-3/PD-L1 bispecific antibody) } \\
\hline NCT03440437 & $\begin{array}{l}\text { Advanced malignancies } \\
\text { that have progressed on } \\
\text { or after prior PD-1/PD-L1 } \\
\text { containing therapy }\end{array}$ & FS118 & 1 & $\begin{array}{l}\text { Not yet recruiting } \\
\text { Estimated completion, May 16, } 2020\end{array}$ \\
\hline
\end{tabular}

PD-1=Programmed death 1; PD-L1= Programmed death ligand 1; CTLA-4=Cytotoxic T lymphocyte antigen 4; IDO-1= Indoleamine 2,3-dioxygenase; $\mathrm{mAb}=$ monoclonal antibody; DART= Dual-Affinity Re-Targeting.

marker for pDCs [70]. LAG-3 on Treg cells inhibits DC proliferation and maturation through the engagement with MHC-II, which is mediated by an ITAM suppressive signaling pathway [33]. In melanoma patient samples, LAG-3 is highly expressed on tumor-infiltrating pDCs, contributing to directing an immune-suppressive environment. LAG-3/MHC-II signaling can stimulate Toll-like receptor (TLR)-independent activation of pDCs with increased IL-6 and impaired IFN- $\alpha$ production [71].

\section{Regulation of LAG-3 expression}

LAG-3 expression and its strong affinity with MHCII substantially up-regulates in inflammatory conditions. IL-2, IL-7, and IL-12 could elevate the expression of LAG-3 on human activated T cells, whereas IL-4, IL6 , tumor necrosis factor- $\alpha$ (TNF- $\alpha$ ), and TNF- $\beta$ have no impact [72]. IL-2 controls $\mathrm{CD}^{+} \mathrm{T}$ cells frequency and enhances sensitivity to Treg suppression. IL-7 takes part in the progress and maintenance of $\mathrm{T}$ cells and is related to a longer-lived memory phenotype [23]. In particular, IL-12 is termedas the most powerful IFN- $\gamma$ inducer, which can up-regulate LAG-3 expression, raise the frequency of LAG-3 positive T cells and NK cells [53, 69]. What's more, LAG-3 expression is also mediated by the zinc-dependent a disintegrin and metalloproteinases (ADAM) through TCR signaling-dependent mechanisms [73]. LAG-3 is cleaved from the cell surface by the two metalloproteases ADAM 10 and ADAM 17 to allow for sufficient T-cell activation. Subsequently, a soluble LAG3 (sLAG-3) is generated and may have competence with membrane LAG-3 to colligate with its ligand [74].

\section{NOVEL LAG-3 LIGANDS EXPRESSED IN THE TUMOR MICROENVIRONMENT}

\section{Galectin-3}

The intriguing fact that LAG-3 modulates the proliferation of $\mathrm{CD} 8^{+} \mathrm{T}$ cells without the engagement of MHC-II has given rise to the exploration of additional LAG-3 ligands [12]. Galectin-3 is a galactoside-binding soluble lectin, which serves as a regulator of antigenspecific T-cell activation [75]. Considering LAG-3 can be extensively glycosylated, which is regarded as a proper target to bind with galectin-3. LAG-3 expression correlates with galectin-3, and functional LAG-3 is indispensable for galectin-3-mediated inhibition of cytotoxic T lymphocyte immune response [58]. Galectin-3 is widely expressed in different cell types; thus interaction with LAG-3 serves to broaden LAG-3's immune regulatory impacts on tumorinfiltrating $\mathrm{CD}^{+} \mathrm{T}$ cells within the TME [75].

\section{Liver sinusoidal endothelial cell lectin}

LSECtin, which belongs to the C-type lectin receptor superfamily and is highly expressed in the liver as well as melanoma cells, is suggested to be an alternative LAG-3 ligand [59, 76]. LSECtin exerts significant inhibitory function in anti-tumor immunity similar to LAG-3. In melanoma samples, LSECtin is commonly expressed in tumor cells, engages in tumor immune escape and promotes tumor growth. LSECtin colligates with LAG-3 to diminish IFN- $\gamma$ production from activated 
T cells [59].

\section{ROLE OF LAG-3 IN AUTOIMMUNE DISORDERS}

Beyond the inhibitory activity of LAG-3 on different types of lymphocytes, LAG-3 may also be necessary to negativelyregulate autoimmunity in many diseaseprone environments [14]. For instance, loss of LAG-3 substantially can accelerate type 1 diabetes in Non-Obese Diabetic (NOD) mice with $100 \%$ incidence. LAG-3 deficient mice can exhibit increased antigen-reactive CD4 and $\mathrm{CD}^{+} \mathrm{T}$ cells infiltration in the islets, accompanied by invasive and rapid insulitis. Meanwhile, LAG-3 blockade also can exaggerate a rapid diabetes onset in wild-type NOD mice [14]. In the B6.SJL mice model, LAG-3 blockade or deficiency may cause elevated susceptibility to Hg-induced autoimmunity, as well as unresponsiveness to tolerance induction [77]. Furthermore, compared with LAG-3 deficiency alone, dual knock out of LAG-3 and PD-1 has been found to quickly induce lethal myocarditis on the BALB/c mice model. This phenotype let us discover synergistic cooperation of LAG-3 and PD-1 in preventing overt autoimmunity and keeping immune homeostasis [78].

\section{THE INTERPLAY BETWEEN LAG-3 AND OTHER IMMUNE CHECKPOINTS}

Interestingly, LAG-3 has remarkable interactions with other immune checkpoints especially PD-1. In T cells co-signaling pathway, TCR binds to MHC to trigger $\mathrm{T}$ cells activation, whereas LAG-3 and other inhibitory immune checkpoints lead to cooperative suppressive effects on TCR signaling (Figure 2).

\section{PD-1/ PD-L1}

Increasing evidence has elucidated that LAG-3 has remarkable cooperation with the quintessential inhibitory immune checkpoints PD-1/PD-L1, which can conjointly mediate immune homeostasis, abrogate autoimmune disease, and enhance tumor-induced tolerance $[15,78,79]$. PD-1 and LAG-3 have been reported to be extensively coexpressed on $\mathrm{CD}^{+}, \mathrm{CD}^{+} \mathrm{T}$ cells and particularly tumorinfiltrating T cells $[40,41,44,57]$. The striking synergy between LAG-3 and PD-1 has been reported in murine melanoma, fibrosarcoma, and colorectal adenocarcinoma models, the combinatorial blockade against LAG-3 and PD-1 effectively eradicate most established tumors, which are largely resistant to single agent treatment. Dual genetic knockout of LAG-3 and PD-1 can delay tumor growth and enable mice to live markedly longer [15]. Likewise, in a murine ovarian cancer model, LAG-3 and PD-1 are synergized to dampen $\mathrm{CD} 8^{+} \mathrm{T}$ cell effector function
[80]. In many tumor samples from patients, sustained co-expression of LAG-3 and PD- 1 can modulate T cells exhaustion state. For instance, in NY-ESO-1 ovarian cancer samples, LAG-3 and PD-1 collaborate to mark dysfunctional $\mathrm{CD}^{+} \mathrm{T}$ cells, both of which attenuate $\mathrm{CD} 8^{+} \mathrm{T}$ cells activation, inhibit cytokines secretion, and take part in immune escape of tumor cells [37]. A recent finding in human NSCLC revealed that over-expression of LAG-3 on TILs significant correlates with PD-1/PDL1 expression, and the patients with both low expression of LAG-3 and PD-L1 indicate a favorable prognosis [44]. Overall, these valuable preclinical data suggest an apparent synergy between LAG-3 and PD-1, providing the backbone for combinational treatment strategies [81]. Currently, a majority of clinical trials are ongoing to explore the therapeutic benefits of simultaneously targeting LAG-3 and PD-1 (Table 3).

\section{CTLA-4}

LAG-3 regulates anti-tumor immune responses interestingly parallels to CTLA-4, a well-known cancer immune checkpoint. Both CTLA-4 and LAG3 can inhibit TCR signaling pathway, arrest cell cycle progression, negatively modulate $\mathrm{T}$ cell homeostasis, trigger the immunosuppressive function of Tregs, and exert essential effects on DCs [82]. However, LAG-3 might be more significant to suppress the activation of primary $\mathrm{T}$ cells and expansion of memory $\mathrm{T}$ cells [30]. The existing intersections of their signal transduction pathways may lead to the intriguing functional similarity of LAG-3 and CTLA-4 [83]. They can both participate in immune tolerance through the co-inhibitory signaling pathway. For instance, in anterior chamber-associated immune deviation (ACAID) mice models, LAG-3 and CTLA-4 on $\mathrm{CD} 4{ }^{+} \mathrm{CD} 25^{+} \mathrm{Foxp}^{+}$Tregs cells are remarkably upregulated, which induces the development of ACAID [84]. Besides, pDCs induced-CD $8^{+}$Foxp $3^{+}$Treg cells could co-express LAG-3 and CTLA-4, suppressing alloreactive $\mathrm{T}$ cells through a CTLA-4-dependent mechanism [85]. In acute graft-versus-host disease (GVHD), both human and murine experimental evidence demonstrates that coblockade using tetravalent CTLA-4-Ig and LAG-3-Ig could synergistically suppress $\mathrm{T}$ cell responses, prevent acute GVHD, and decrease GVHD fatality rates as well [86]. A recent study, which assesses the therapeutic effects of the CTLA-4 antibody ipilimumab, found ipilimumab might increase frequencies of tumor-infiltrating $\mathrm{T}$ cells expressing LAG-3 in metastatic melanoma patients [87]. Also, it is notable that a new phase I/II clinical trial (NCT03459222) has recently been opened to investigate the efficacy of triple targeting LAG-3, PD-1, and CTLA4 , which may be a novel combinatorial strategy in cancer treatment and autoimmune disorders. 


\section{Targeting LAG-3 in cancer immunotherapy}

Immune checkpoints therapy has been reshaping the intriguing landscape of cancer immunotherapy; however, tumor intrinsic resistance is a challenging problem. The unmet need is to identify more alternative therapeutic targets, therefore unleash the full armamentarium of immune checkpoints therapy. Strikingly, the emerging immune checkpoint LAG-3 is considered as a highly promising therapeutic target [8]. Anti-LAG-3 antibody can not only promote effector $\mathrm{T}$ cells activity but also inhibit Treg-induced suppressive function in the TME[88]. What's more, in light of the interaction between LAG-3 and other immune checkpoints, targeting LAG-3 along with other checkpoints especially PD-1 holds considerable promise in cancer immunotherapy [89]. There are some approaches involving LAG-3-targeted immunotherapy in different phases of clinical development (Table 3; Clinical Trials.gov).

The first is IMP321, a soluble LAG-3Ig fusion protein which has been investigated in clinical trials since $2006[16-18,90]$. IMP321 has already completed three clinical trials in renal cell carcinoma, metastatic breast carcinoma, and melanoma with moderate success [16$18]$ and is still progressing in new clinical trials to further exploring therapeutic benefits. IMP321 has been found to be a systemic APC activator to enhance the proliferation of DCs, lessen Treg cells immunosuppressive effects, and allow for optimal cross antigen presenting to $\mathrm{CD} 8^{+} \mathrm{T}$ cells [90]. The second is antagonistic LAG-3 antibodies which release the brakes of the anti-tumor immune response, such as BMS-986016, LAG525, REGN3767and TSR033. Considerable clinical trials are proceeding to evaluate LAG-3 antibody alone or in combination with PD-1 antibody [91] (Table 3). The third is first-in-class bispecific protein binding PD-1 and LAG-3 such as MGD013 and FS118, which are currently undergoing phase I clinical trials.

As the first anti-LAG-3 antibody to develop in 2013, BMS-986016 is actively being evaluated in twelve phase I or II clinical trials in many hematological and solid tumors (Table 3; Clinical Trias.gov). Notably, the combination of BMS-986016 and nivolumab (anti-PD-1) exhibited exciting preliminary efficacy in melanoma patients who were refractory to the previous anti-PD-1/PD-L1 therapy (NCT01968109). The combination therapy showed a safety profile analogous to nivolumab monotherapy, with uncommon grade $3 / 4$ adverse events [19]. Based on the updated data at the 2017 ESMO Congress, the combination therapy can increase objective response rates from $5 \%$ to $18 \%$ in patients with LAG-3-positive tumors. Patients with LAG-3 expression $\geq 1 \%$ are more likely to derive enhanced clinical efficacy [20]. These results are of particular interest for the ongoing more extensive exploration of LAG-3 as an alternative immunotherapy target and potential predictive biomarker [92]. Moreover, we are looking forward to more well-controlled phase III clinical trials to confirm the clinical benefits of LAG-3targeted immunotherapy.

\section{CONCLUSION AND PERSPECTIVES}

Cancer immunotherapy and tumor microenvironment have been at the forefront of cancer research over the past several decades. Waves of immune checkpoints therapy especially targeting PD-1/PD-L1 have led to remarkable success in treating advanced malignancies. However, most patients do not respond and even develop resistance, bringing about a daunting challenge. Therefore, the research focus has altered to dig deeply into the TME for additional therapeutic targets that can lead to combination therapy. Conspicuously, LAG3 plays an exceptional inhibitory role in maintaining immune homeostasis, which is expressed on various types of lymphocytes, accompanied by cooperation with other immune checkpoints especially PD-1. LAG-3 may be a promising therapeutic target in cancer immunotherapy, and the combination of BMS-986016 (anti-LAG-3) plus nivolumab (anti-PD-1) exhibited compelling clinical benefits in melanoma patients who are unresponsive to prior anti-PD-1/PD-L1 therapy with more well-designed clinical trials moving forward.

Since the current research is just a tip of the iceberg, there remain vital questions before optimizing the significance of LAG-3 in the TME and cancer immunotherapy. First, the precise molecular mechanisms by which LAG-3 mediates the TCR signaling pathway and function are largely unknown. Considering the unique intracellular cytoplasmic domain of LAG-3 such as KEELE, we may propose that LAG-3 biology is unusual and distinct from other immune checkpoints. A thorough understanding the mode of LAG-3's action is a top priority and can provide a consolidating foundation for future therapeutic development. Second, due to the immune regulatory role of LAG-3 on various types of lymphocytes, how to best apply the differential function in clinical immunotherapy remains an interesting question. Compared with the effects of LAG-3 on effector T cells and Tregs, the specialized roles of LAG-3 in pDCs and NK cells are relatively unexplored. Third, from a mechanistic view, what leads to the complicated interaction of LAG-3 and other immune checkpoints particularly PD-1? How does LAG-3 influence tumor progression when anti-PD-1 does not work? So can LAG-3 expression serve as a robust predictive biomarker to predict response to anti-PD-1/PDL1 immunotherapy? Further elucidation of these crucial questions may help to design effective combinatorial therapy strategies and overcome possible resistance. The heightened interests will be on the therapeutic benefits of combinatorial immunotherapy of PD-1 and LAG-3. Last but not least, identifying ideal combinatorial strategies between LAG-3-targeted immunotherapy and other front- 
line modalities, including chemotherapy, radiotherapy as well as targeted therapy may also show tantalizing promises in clinical practice. Taken together, the significant role of LAG-3 in the TME has paved the way for LAG-3-targeted immunotherapy. More prospective clinical studies targeting LAG-3 alone or in combination with PD-1 are further needed, to facilitate the translation of our understanding from bench to bedside.

\section{ACKNOWLEDGMENTS}

This work was supported by grants from the National Undergraduate Innovation Project of China (No.201710486100) and Public Welfare Technology Application Research of Zhejiang Province (No. 2016C33236).

\section{CONFLICT OF INTERESTS}

The authors declare no conflict of interest.

\section{REFERENCES}

1. Joyce JA, Fearon DT. T cell exclusion, immune privilege, and the tumor microenvironment. Science. 2015; 348:7480.

2. Spano D, Zollo M. Tumor microenvironment: a main actor in the metastasis process. Clin Exp Metastasis. 2012; 29:381-395.

3. Son B, Lee S, Youn H, Kim E, Kim W, Youn B. The role of tumor microenvironment in therapeutic resistance. Oncotarget. 2017; 8:3933-3945.

4. Zhao X, Subramanian S. Intrinsic Resistance of Solid Tumors to Immune Checkpoint Blockade Therapy. Cancer Res. 2017;77:817-822.

5. Sharma P, Allison JP. The future of immune checkpoint therapy. Science. 2015; 348:56-61.

6. Brahmer JR, Tykodi SS, Chow LQ, Hwu WJ, Topalian SL, Hwu P, Drake CG, Camacho LH, Kauh J, Odunsi K, Pitot HC, Hamid O, Bhatia S, et al. Safety and activity of antiPD-L1 antibody in patients with advanced cancer. N Engl J Med. 2012; 366:2455-2465.

7. Marconcini R, Spagnolo F, Stucci LS, Ribero S, Marra E, Rosa F, Picasso V, Di Guardo L, Cimminiello C, Cavalieri S, Orgiano L, Tanda E, Spano L, et al. Current status and perspectives in immunotherapy for metastatic melanoma. Oncotarget. 2018; 9:12452-12470.

8. He Y, Rivard CJ, Rozeboom L, Yu H, Ellison K, Kowalewski A, Zhou C, Hirsch FR. Lymphocyte-activation gene-3, an important immune checkpoint in cancer. Cancer Sci. 2016; 107:1193-1197.

9. Das M, Zhu C, Kuchroo VK. (2017) Tim-3 and its role in regulating anti-tumor immunity. Immunol Rev. 2017; 276:97-111.
10. Villarroel-Espindola F, Yu X, Datar I, Mani N, Sanmamed M, Velcheti V, Syrigos K, Toki M, Zhao H, Chen L, Herbst RS, Schalper KA. Spatially Resolved and Quantitative Analysis of VISTA/PD-1H as a Novel Immunotherapy Target in Human Non-Small Cell Lung Cancer. Clin Cancer Res. 2018; 24:1562-1573.

11. Cheng H, Janakiram M, Borczuk A, Lin J, Qiu W, Liu H, Chinai JM, Halmos B, Perez-Soler R, Zang X HHLA2, a New Immune Checkpoint Member of the B7 Family, Is Widely Expressed in Human Lung Cancer and Associated with EGFR Mutational Status. Clin Cancer Res. 2017; 23:825-832.

12. Andrews LP, Marciscano AE, Drake CG, Vignali DA. LAG3 (CD223) as a cancer immunotherapy target. Immunol Rev. 2017; 276:80-96.

13. Goldberg MV, Drake CG. LAG-3 in Cancer Immunotherapy. Curr Top Microbiol Immunol. 2011; 344:269-278.

14. Bettini M, Szymczak-Workman AL, Forbes K, Castellaw AH, Selby M, Pan X, Drake CG, Korman AJ, Vignali DA. Cutting edge: accelerated autoimmune diabetes in the absence of LAG-3. J Immunol. 2011; 187:3493-3498.

15. Woo SR, Turnis ME, Goldberg MV, Bankoti J, Selby M, Nirschl CJ, Bettini ML, Gravano DM, Vogel P, Liu CL, Tangsombatvisit S, Grosso JF, Netto G, et al. Immune inhibitory molecules LAG-3 and PD-1 synergistically regulate T-cell function to promote tumoral immune escape. Cancer Res. 2012; 72:917-927.

16. Brignone C, Escudier B, Grygar C, Marcu M, Triebel F. A phase I pharmacokinetic and biological correlative study of IMP321, a novel MHC class II agonist, in patients with advanced renal cell carcinoma. Clin Cancer Res. 2009; 15:6225-6231.

17. Brignone C, Gutierrez M, Mefti F, Brain E, Jarcau R, Cvitkovic F, Bousetta N, Medioni J, Gligorov J, Grygar C, Marcu M, Triebel F. First-line chemoimmunotherapy in metastatic breast carcinoma: combination of paclitaxel and IMP321 (LAG-3Ig) enhances immune responses and antitumor activity. J Transl Med. 2010; 8:71.

18. Romano E, Michielin O, Voelter V, Laurent J, Bichat H, Stravodimou A, Romero P, Speiser DE, Triebel F, Leyvraz S, Harari A. MART-1 peptide vaccination plus IMP321 (LAG-3Ig fusion protein) in patients receiving autologous PBMCs after lymphodepletion: results of a Phase I trial. J Transl Med. 2014; 12:97.

19. Ascierto PA, Melero I, Bhatia S, Bono P, Sanborn RE, Lipson EJ, Callahan MK, Gajewski T, Gomez-Roca CA, Hodi FS, Curigliano G, Nyakas M, Preusser M, et al. Initial efficacy of anti-lymphocyte activation gene-3 (anti-LAG-3; BMS-986016) in combination with nivolumab (nivo) in pts with melanoma (MEL) previously treated with anti-PD-1/ PD-L1 therapy. J Clin Oncol. 2017; 35:9520.

20. Ascierto PA, Bono P, Bhatia S, Melero I, Nyakas M, Svane I, Larkin J, Gomez-Roca CA, Schadendorf D, Dummer R, Marabelle A, Hoeller C, Maurer M, et al. Efficacy of BMS986016, a monoclonal antibody that targets lymphocyte 
activation gene-3 (LAG-3), in combination with nivolumab in pts with melanoma. In: ESMO 2017 Congress, Madrid, Spain.

21. Triebel F, Jitsukawa S, Baixeras E, Roman-Roman S, Genevee C, Viegas-Pequignot E, Hercend T . LAG-3, a novel lymphocyte activation gene closely related to CD4. J Exp Med. 1990; 171:1393-1405.

22. Demeure CE, Wolfers J, Martin-Garcia N, Gaulard P, Triebel F. T Lymphocytes infiltrating various tumour types express the MHC class II ligand lymphocyte activation gene-3 (LAG-3): role of LAG-3/MHC class II interactions in cell-cell contacts. Eur J Cancer. 2001; 37:1709-1718.

23. Durham NM, Nirschl CJ, Jackson CM, Elias J, Kochel CM, Anders RA, Drake CG. Lymphocyte Activation Gene 3 (LAG-3) modulates the ability of CD4 T-cells to be suppressed in vivo. PLoS One. 2014; 9:e109080.

24. Pena J, Jones NG, Bousheri S, Bangsberg DR, Cao H. Lymphocyte activation gene-3 expression defines a discrete subset of HIV-specific CD8 $+\mathrm{T}$ cells that is associated with lower viral load. AIDS Res Hum Retroviruses. 2014; 30:535-541.

25. Huang CT, Workman CJ, Flies D, Pan X, Marson AL, Zhou G, Hipkiss EL, Ravi S, Kowalski J, Levitsky HI, Powell JD, Pardoll DM, Drake CG, et al. Role of LAG-3 in regulatory T cells. Immunity. 2004; 21:503-513.

26. Huard B, Tournier M, Triebel F. LAG-3 does not define a specific mode of natural killing in human. Immunol Lett. 1998; 61:109-112.

27. Kisielow M, Kisielow J, Capoferri-Sollami G, Karjalainen K. Expression of lymphocyte activation gene 3 (LAG-3) on B cells is induced by T cells. Eur J Immunol. 2005; 35:2081-2088.

28. Andreae S, Buisson S, Triebel F. MHC class II signal transduction in human dendritic cells induced by a natural ligand, the LAG-3 protein (CD223). Blood. 2003; 102:2130-2137.

29. Hannier S, Tournier M, Bismuth G, Triebel F. CD3/ TCR complex-associated lymphocyte activation gene-3 molecules inhibit CD3/TCR signaling. J Immunol. 1998; 161:4058-4065.

30. Workman CJ, Cauley LS, Kim IJ, Blackman MA, Woodland DL, Vignali DA. Lymphocyte activation gene-3 (CD223) regulates the size of the expanding $\mathrm{T}$ cell population following antigen activation in vivo. J Immunol. 2004; 172:5450-5455.

31. Macon-Lemaitre L, Triebel F. The negative regulatory function of the lymphocyte-activation gene-3 co-receptor (CD223) on human T cells. Immunology. 2005; 115:170178.

32. Hemon P, Jean-Louis F, Ramgolam K, Brignone C, Viguier M, Bachelez H, Triebel F, Charron D, Aoudjit F, Al-Daccak R, Michel L. MHC class II engagement by its ligand LAG-3 (CD223) contributes to melanoma resistance to apoptosis. J Immunol.2011; 186:5173-5183.
33. Liang B, Workman C, Lee J, Chew C, Dale BM, Colonna L, Flores M, Li N, Schweighoffer E, Greenberg S, Tybulewicz V, Vignali D, Clynes R. Regulatory T cells inhibit dendritic cells by lymphocyte activation gene- 3 engagement of MHC class II. J Immunol. 2008; 180:5916-5926.

34. Gandhi MK, Lambley E, Duraiswamy J, Dua U, Smith C, Elliott S, Gill D, Marlton P, Seymour J, Khanna R. Expression of LAG-3 by tumor-infiltrating lymphocytes is coincident with the suppression of latent membrane antigenspecific CD8+ T-cell function in Hodgkin lymphoma patients. Blood. 2006; 108:2280-2289.

35. Shapiro M, Herishanu Y, Katz BZ, Dezorella N, Sun C, Kay S, Polliack A, Avivi I, Wiestner A, Perry C. Lymphocyte activation gene 3: a novel therapeutic target in chronic lymphocytic leukemia. Haematologica. 2017; 102:874-882.

36. Chen J, Chen Z. The effect of immune microenvironment on the progression and prognosis of colorectal cancer. Med Oncol. 2014; 31:82.

37. Matsuzaki J, Gnjatic S, Mhawech-Fauceglia P, Beck A, Miller A, Tsuji T, Eppolito C, Qian F, Lele S, Shrikant P, Old LJ, Odunsi K. Tumor-infiltrating NY-ESO-1-specific CD8+ T cells are negatively regulated by LAG-3 and PD-1 in human ovarian cancer. Proc Natl Acad Sci U S A. 2010; 107:7875-7880.

38. Li FJ, Zhang Y, Jin GX, Yao L, Wu DQ. Expression of LAG-3 is coincident with the impaired effector function of HBV-specific CD8(+) T cell in HCC patients. Immunol Lett. 2013; 150:116-122.

39. Giraldo NA, Becht E, Pages F, Skliris G, Verkarre V, Vano Y, Mejean A, Saint-Aubert N, Lacroix L, Natario I, Lupo A, Alifano M, Damotte D, et al. Orchestration and prognostic significance of immune checkpoints in the microenvironment of primary and metastatic renal cell cancer. Clin Cancer Res. 2015; 21:3031-3040.

40. Takaya S, Saito H, Ikeguchi M. Upregulation of Immune Checkpoint Molecules, PD-1 and LAG-3, on CD4+ and CD8+ T Cells after Gastric Cancer Surgery. Yonago Acta Med. 2015; 58:39-44.

41. Yang Z-Z, Kim HJ, Villasboas JC, Chen Y-P, Price-Troska T, Jalali S, Wilson M, Novak AJ, Ansell SM. Expression of LAG-3 defines exhaustion of intratumoral PD-1(+) T cells and correlates with poor outcome in follicular lymphoma. Oncotarget. 2017; 8:61425-61439.

42. Norstrom MM, Radestad E, Sundberg B, Mattsson J, Henningsohn L, Levitsky V, Uhlin M . Progression of benign prostatic hyperplasia is associated with proinflammatory mediators and chronic activation of prostateinfiltrating lymphocytes. Oncotarget. 2016; 7:23581-23593.

43. Deng WW, Mao L, Yu GT, Bu LL, Ma SR, Liu B, Gutkind JS, Kulkarni AB, Zhang WF, Sun ZJ . LAG-3 confers poor prognosis and its blockade reshapes antitumor response in head and neck squamous cell carcinoma. Oncoimmunology. 2016; 5:e1239005.

44. He Y, Yu H, Rozeboom L, Rivard CJ, Ellison K, 
Dziadziuszko R, Suda K, Ren S, Wu C, Hou L, Zhou C, Hirsch FR. LAG-3 Protein Expression in Non-Small Cell Lung Cancer and Its Relationship with PD-1/PD-L1 and Tumor-Infiltrating Lymphocytes. J Thorac Oncol. 2017; 12:814-823.

45. Marcq E, Waele J, Audenaerde JV, Lion E, Santermans E, Hens N, Pauwels P, van Meerbeeck JP, Smits ELJ. Abundant expression of TIM-3, LAG-3, PD-1 and PDL1 as immunotherapy checkpoint targets in effusions of mesothelioma patients. Oncotarget. 2017; 8:89722-89735.

46. Burugu S, Gao D, Leung S, Chia SK, Nielsen TO. LAG$3+$ tumor infiltrating lymphocytes in breast cancer: clinical correlates and association with PD-1/PD-L1+ tumors. Ann Oncol. 2017; 28:2977-2984.

47. Yanik EL, Kaunitz GJ, Cottrell TR, Succaria F, McMiller TL, Ascierto ML, Esandrio J, Xu H, Ogurtsova A, Cornish T, Lipson EJ, Topalian SL, Engels EA, et al. Association of HIV Status With Local Immune Response to Anal Squamous Cell Carcinoma: Implications for Immunotherapy. JAMA Oncol. 2017; 3:974-978.

48. Meng Q, Liu Z, Rangelova E, Poiret T, Ambati A, Rane L, Xie S, Verbeke C, Dodoo E, Del Chiaro M, Lohr M, Segersvard R, Maeurer MJ. Expansion of Tumor-reactive T Cells From Patients With Pancreatic Cancer. J Immunother. 2016; 39:81-89.

49. Santoiemma PP, Powell DJ Jr. Tumor infiltrating lymphocytes in ovarian cancer. Cancer Biol Ther. 2015; 16:807-820.

50. Goding SR, Wilson KA, Xie Y, Harris KM, Baxi A, Akpinarli A, Fulton A, Tamada K, Strome SE, Antony PA. Restoring immune function of tumor-specific CD4+ $\mathrm{T}$ cells during recurrence of melanoma. J Immunol. 2013;190:4899-4909.

51. Huard B, Tournier M, Hercend T, Triebel F, Faure F. Lymphocyte-activation gene 3/major histocompatibility complex class II interaction modulates the antigenic response of CD4+ T lymphocytes. Eur J Immunol. 1994; 24:3216-3221.

52. Workman CJ, Dugger KJ, Vignali DA. Cutting edge: molecular analysis of the negative regulatory function of lymphocyte activation gene-3. J Immunol. 2002; 169:53925395.

53. Di Carlo E, Cappello P, Sorrentino C, D'Antuono T, Pellicciotta A, Giovarelli M, Forni G, Musiani P, Triebel F. Immunological mechanisms elicited at the tumour site by lymphocyte activation gene-3 (LAG-3) versus IL-12: sharing a common Th1 anti-tumour immune pathway. J Pathol. 2005; 205:82-91.

54. Scala E, Carbonari M, Del Porto P, Cibati M, Tedesco T, Mazzone AM, Paganelli R, Fiorilli M. Lymphocyte activation gene-3 (LAG-3) expression and IFN-gamma production are variably coregulated in different human $\mathrm{T}$ lymphocyte subpopulations. J Immunol. 1998; 161:489493.
55. Grosso JF, Kelleher CC, Harris TJ, Maris CH, Hipkiss EL, De Marzo A, Anders R, Netto G, Getnet D, Bruno TC, Goldberg MV, Pardoll DM, Drake CG. LAG-3 regulates $\mathrm{CD} 8+\mathrm{T}$ cell accumulation and effector function in murine self- and tumor-tolerance systems. J Clin Invest. 2007; 117:3383-3392.

56. Sittig SP, Kollgaard $\mathrm{T}$, Gronbaek $\mathrm{K}$, Idorn $\mathrm{M}$, Hennenlotter J, Stenzl A, Gouttefangeas C, Thor Straten P. Clonal expansion of renal cell carcinoma-infiltrating $\mathrm{T}$ lymphocytes. Oncoimmunology. 2013; 2:e26014.

57. Mishra AK, Kadoishi T, Wang X, Driver E, Chen Z, Wang XJ, Wang JH. Squamous cell carcinomas escape immune surveillance via inducing chronic activation and exhaustion of CD8+ T Cells co-expressing PD-1 and LAG-3 inhibitory receptors. Oncotarget. 2016; 7:81341-81356.

58. Kouo T, Huang L, Pucsek AB, Cao M, Solt S, Armstrong T, Jaffee E. Galectin-3 Shapes Antitumor Immune Responses by Suppressing CD8+ T Cells via LAG-3 and Inhibiting Expansion of Plasmacytoid Dendritic Cells. Cancer Immunol Res. 2015; 3:412-423.

59. Xu F, Liu J, Liu D, Liu B, Wang M, Hu Z, Du X, Tang L, He F. LSECtin expressed on melanoma cells promotes tumor progression by inhibiting antitumor T-cell responses. Cancer Res. 2014; 74:3418-3428.

60. Bos R, Marquardt KL, Cheung J, Sherman LA. Functional differences between low- and high-affinity CD8(+) T cells in the tumor environment. Oncoimmunology. 2012; 1:12391247.

61. Farsam V, Hassan ZM, Zavaran-Hosseini A, Noori S, Mahdavi M, Ranjbar M. Antitumor and immunomodulatory properties of artemether and its ability to reduce CD4+ CD25+ FoxP3+ T reg cells in vivo. Int Immunopharmacol. 2011; 11:1802-1808.

62. Park HJ, Kusnadi A, Lee EJ, Kim WW, Cho BC, Lee IJ, Seong J, Ha SJ. Tumor-infiltrating regulatory T cells delineated by upregulation of PD-1 and inhibitory receptors. Cell Immunol . 2012; 278:76-83.

63. Camisaschi C, Casati C, Rini F, Perego M, De Filippo A, Triebel F, Parmiani G, Belli F, Rivoltini L, Castelli C. LAG-3 expression defines a subset of CD4(+)CD25(high) Foxp3(+) regulatory $\mathrm{T}$ cells that are expanded at tumor sites. J Immunol. 2010; 184:6545-6551.

64. Wei T, Zhang J, Qin Y, Wu Y, Zhu L, Lu L, Tang G, Shen Q. Increased expression of immunosuppressive molecules on intratumoral and circulating regulatory $\mathrm{T}$ cells in non-smallcell lung cancer patients. Am J Cancer Res. 2015; 5:21902201.

65. Miyazaki T, Dierich A, Benoist C, Mathis D. Independent modes of natural killing distinguished in mice lacking Lag3. Science. 1996; 272:405-408.

66. Byun HJ, Jung WW, Lee DS, Kim S, Kim SJ, Park CG, Chung HY, Chun T. Proliferation of activated CD1drestricted NKT cells is down-modulated by lymphocyte activation gene- 3 signaling via cell cycle arrest in $\mathrm{S}$ phase. 
Cell Biol Int. 2007; 31:257-262.

67. Juno JA, Stalker AT, Waruk JL, Oyugi J, Kimani M, Plummer FA, Kimani J, Fowke KR . Elevated expression of LAG-3, but not PD-1, is associated with impaired iNKT cytokine production during chronic HIV-1 infection and treatment. Retrovirology. 2015; 12:17.

68. Kritikou JS, Dahlberg CI, Baptista MA, Wagner AK, Banerjee PP, Gwalani LA, Poli C, Panda SK, Karre K, Kaech SM, Wermeling F, Andersson J, Orange JS, et al. IL-2 in the tumor microenvironment is necessary for Wiskott-Aldrich syndrome protein deficient NK cells to respond to tumors in vivo. Sci Rep. 2016; 6:30636.

69. Sun H, Sun C, Xiao W. Expression regulation of coinhibitory molecules on human natural killer cells in response to cytokine stimulations. Cytokine. 2014; 65:3341.

70. Workman CJ, Wang Y, El Kasmi KC, Pardoll DM, Murray PJ, Drake CG, Vignali DA. LAG-3 regulates plasmacytoid dendritic cell homeostasis. J Immunol. 2009; 182:18851891.

71. Camisaschi C, De Filippo A, Beretta V, Vergani B, Villa A, Vergani E, Santinami M, Cabras AD, Arienti F, Triebel F, Rodolfo M, Rivoltini L, Castelli C . Alternative activation of human plasmacytoid DCs in vitro and in melanoma lesions: involvement of LAG-3. J Invest Dermatol. 2014; 134:1893-1902.

72. Bruniquel D, Borie N, Hannier S, Triebel F. Regulation of expression of the human lymphocyte activation gene-3 (LAG-3) molecule, a ligand for MHC class II. Immunogenetics. 1998; 48:116-124.

73. Li N, Wang Y, Forbes K, Vignali KM, Heale BS, Saftig P, Hartmann D, Black RA, Rossi JJ, Blobel CP, Dempsey PJ, Workman CJ, Vignali DA. Metalloproteases regulate T-cell proliferation and effector function via LAG-3. EMBO J. 2007; 26:494-504.

74. Li N, Workman CJ, Martin SM, Vignali DA. Biochemical analysis of the regulatory $\mathrm{T}$ cell protein lymphocyte activation gene-3 (LAG-3; CD223). J Immunol. 2004; 173:6806-6812.

75. Dumic J, Dabelic S, Flogel M. Galectin-3: an open-ended story. Biochim Biophys Acta. 2006; 1760 (4):616-635.

76. Liu W, Tang L, Zhang G, Wei H, Cui Y, Guo L, Gou Z, Chen X, Jiang D, Zhu Y, Kang G, He F. Characterization of a novel C-type lectin-like gene, LSECtin: demonstration of carbohydrate binding and expression in sinusoidal endothelial cells of liver and lymph node. J Biol Chem. 2004; 279:18748-18758.

77. Jha V, Workman CJ, McGaha TL, Li L, Vas J, Vignali DA, Monestier M. Lymphocyte Activation Gene-3 (LAG-3) negatively regulates environmentally-induced autoimmunity. PLoS One. 2014; 9:e104484.

78. Okazaki T, Okazaki IM, Wang J, Sugiura D, Nakaki F, Yoshida T, Kato Y, Fagarasan S, Muramatsu M, Eto T, Hioki K, Honjo T. PD-1 and LAG-3 inhibitory co-receptors act synergistically to prevent autoimmunity in mice. J Exp Med. 2011; 208:395-407.

79. Okagawa T, Konnai S, Deringer JR, Ueti MW, Scoles GA, Murata S, Ohashi K, Brown WC. Cooperation of PD-1 and LAG-3 Contributes to T-Cell Exhaustion in Anaplasma marginale-Infected Cattle. Infect Immun. 2016; 84:27792790.

80. Huang RY, Eppolito C, Lele S, Shrikant P, Matsuzaki J, Odunsi K. LAG3 and PD1 co-inhibitory molecules collaborate to limit $\mathrm{CD} 8+\mathrm{T}$ cell signaling and dampen antitumor immunity in a murine ovarian cancer model. Oncotarget. 2015; 6:27359-27377.

81. Dempke WCM, Fenchel K, Uciechowski P, Dale SP. Second- and third-generation drugs for immuno-oncology treatment-The more the better? Eur J Cancer. 2017; 74:5572.

82. Baumeister SH, Freeman GJ, Dranoff G, Sharpe AH. Coinhibitory Pathways in Immunotherapy for Cancer. Annu Rev Immunol. 2016; 34:539-573.

83. Workman CJ, Vignali DA. The CD4-related molecule, LAG-3 (CD223), regulates the expansion of activated T cells. Eur J Immunol. 2003; 33:970-979.

84. Zhu X, Yang P, Zhou H, Li B, Huang X, Meng Q, Wang L, Kijlstra A. CD4+CD25+Tregs express an increased LAG3 and CTLA-4 in anterior chamber-associated immune deviation. Graefes Arch Clin Exp Ophthalmol. 2007; 245:1549-1557.

85. Boor PP, Metselaar HJ, Jonge S, Mancham S, van der Laan LJ, Kwekkeboom J. Human plasmacytoid dendritic cells induce CD8(+) LAG-3(+) Foxp3(+) CTLA-4(+) regulatory $\mathrm{T}$ cells that suppress allo-reactive memory $\mathrm{T}$ cells. Eur $\mathrm{J}$ Immunol. 2011; 41:1663-1674.

86. Cho H, Chung YH. Construction, and in vitro and in vivo analyses of tetravalent immunoadhesins. J Microbiol Biotechnol. 2012; 22:1066-1076.

87. Bjoern J, Lyngaa R, Andersen R, Rosenkrantz LH, Hadrup SR, Donia M, Svane IM. Influence of ipilimumab on expanded tumour derived $\mathrm{T}$ cells from patients with metastatic melanoma. Oncotarget. 2017; 8:27062-27074.

88. Gagliani N, Magnani CF, Huber S, Gianolini ME, Pala M, Licona-Limon P, Guo B, Herbert DR, Bulfone A, Trentini F, Di Serio C, Bacchetta R, Andreani M, et al. Coexpression of CD49b and LAG-3 identifies human and mouse T regulatory type 1 cells. Nat Med. 2013; 19:739-746.

89. Vilgelm AE, Johnson DB, Richmond A. Combinatorial approach to cancer immunotherapy: strength in numbers. J Leukoc Biol. 2016; 100:275-290.

90. Legat A, Maby-El Hajjami H, Baumgaertner P, Cagnon L, Abed Maillard S, Geldhof C, Iancu EM, Lebon L, Guillaume P, Dojcinovic D, Michielin O, Romano E, Berthod G, et al. Vaccination with LAG-3Ig (IMP321) and Peptides Induces Specific CD4 and CD8 T-Cell Responses in Metastatic Melanoma Patients--Report of a Phase I/IIa Clinical Trial. Clin Cancer Res. 2016; 22:1330-1340. 
91. Hahn AW, Gill DM, Pal SK, Agarwal N. The future of immune checkpoint cancer therapy after PD-1 and CTLA4. Immunotherapy. 2017; 9:681-692.

92. Ascierto PA, McArthur GA. Checkpoint inhibitors in melanoma and early phase development in solid tumors: what's the future? J Transl Med. 2017; 15:173. 